\title{
Career Progression of Women Academics in Pakistani Universities: Enablers and
}

\author{
Barriers \\ * Dr. Saeeda Shah \\ ** Ms. Samra Bashir \\ *** Dr. Muhammad Amin (Corresponding Author)
}

\begin{abstract}
There is a dramatic increase in the number of women students in higher educational institutions but this had not been matched by growth in the number of women in senior leadership positions in Pakistani Universities. The current study was designed to explore the barriers and enablers that influence the professional development of women academics in Pakistan. Furthermore, the study investigated how female academicians manage the balance in their personal and professional life. Semi-structured interviews followed by a probing strategy were conducted to seek responses to these questions. 10 female academicians were selected purposively from two public sector universities of Lahore. Thematic analysis was conducted by using an inductive approach. Member check was applied for the reliability of themes drawn from the data. Each theme was explored in-depth and themes emerged from a smaller number of women were treated separately under the category of unique theme. Women considered their professional career development as a source of pride and gratification. Women academicians at the senior level enjoyed leadership roles as compared to young academicians; who were more involved in teaching and research. Females complained that they had not the information on policies relevant to their job and merit is neglected most of the time by higher authorities. Females claimed that they faced a biased attitude of their senior male colleagues/heads of departments but were highly motivated to face these challenges at the workplace.
\end{abstract}

Keywords: Career Progression, Academia, Enablers, Barriers

Introduction

International statistics show that women enrolment has rapidly increased in institutions of higher education and has increased almost twice as fast as that of men since 1970 (UNESCO, 2010). But this rapid increase in women enrolment at institutions of higher education has not been affecting the number of women at senior management roles in universities. Mostly male members are appointed at senior management positions (Morley, 2006). The less representation of women at higher academic levels within universities is a matter of continuous unease for women academicians. (Avin et al. 2015; Cook \& Glass 2014; Howe-Walsh et al. 2014; Taylor-Abdulai et al. 2014; Machado-Taylor \& Ozkanli 2013; Zeng 2011; Montez et al. 2003). Researchers have identified some barriers that hinder the advancement of women in academia, including lack of advanced education and finances, less support from management to participate in work/life programs, occupational sex segregation, lack of role-models, and attitudinal biases (Hannum, Muhly, Shockley-Zalabak \& White, 2015; Bombuwela \& De Alwis, 2013; Vinkenburg, Engen, Eagly \& Johannesen-Schmidt, 2011). Batool, Sajid, and Shaheen (2013) conducted a quantitative study to know the status of women's representation in the management of Higher Education (HE) in Pakistan. They claimed that women are facing structural barriers such as lack of mentoring and networking, gender inequality, ignorance in selection and promotion process in their career advancement.

Women's problems in career progression are persistent theme in studies in the global north and south, including studies from Pakistan (Bagilhole \& White, 2011; Blackmore \& Sachs, 2001; Rab, 2010; Shah, 2001). Keeping in view the specific 'socio-religious' role of women in Pakistan, the present study explored the enablers and disablers in the career development of women academics and

\footnotetext{
* Reader in School of Education, University of Leicester, England, UK Email: sjas2@ @eicester.ac.uk

** Lecturer in Education, University of Education, Lahore Email: samrabashir@ue.edu.pk

*** University of Education, Lahore Email: amin@ue.edu.pk
} 
their role in their professional journey. This study was conducted under the direction of British Academy funded project titled "Research Capacity Building through International Partnership for mapping women academics' careers in Pakistan". The research has significant practical implications in defining multidimensional roles of women in academia in Pakistan by showing how they engraved their way out of conventional images of societal and personal constraints to become a successful professional. This study will provide deeper insight into the journey of career progression of women academics by exploring the factors that enable them to continue their profession until the desirable position. The second focus of this study was to discover problems, challenges, and critical moments discouraging women in their career progression

\section{Research Questions}

The study seeks the answer of following questions:

1. What are the factors that enable women academicians to adapt and continue their profession until the desirable position?

2. What are the different coping strategies used by women academicians to come out from workplace stress?

3. What are the problems, challenges, and critical moments discouraging women in their career progression?

\section{Literature Review}

European countries claimed that they are given priority to gender equality more than any region of the world. But as a matter of fact, women are found less at senior academic positions in universities. Issues of women under-representation are also found in other countries of the world e.g. Canada, New Zealand, Africa, Australia, and Asia (Stanford Report, 2014; Wilson, Gadbois \& Nichol, 2008).

South Asian countries are also facing under-representation of women in institutions of higher education. Statistics from India revealed that female academics is less than $40 \%$ in universities. Muslim women are also observed less in numbers in Indian Academics. (Morley \& Crossouard, 2015). Chanana (2012) from India reported that female student participation in HE is more than male students, but female academics are absent from higher ranks of educational management. Indicating the reasons, she said that it might be due to religious or socio-cultural landscape across India. Bangladesh another South Asian country also facing the issue of less representation of females in Universities. Findings of a survey conducted at universities of Bangladesh showed that the induction of female academicians is less than 5\% from 2010 to 2012. (Morley \& Crossouard, 2015). Explaining the situation of women representation in higher education of Nepal, Grove (2013) shared that women are ignored to be selected for higher academic positions because they are unable to make good decisions as they have to perform multiple roles in their personal lives e.g. as a; wife, mother and caretaker of the family, which restrict their ability to perform well at decision-making level.

Women in Pakistan comprise 49.2\%. They have attained 52\% of all types of professional jobs (Catalyst, 2014). However, the women are usually performing duties at lower ranks. One major public sector university in Pakistan has a huge variance between the number of male and female workers, working on various hierarchical levels. In the universities of Pakistan, mostly women are working as lecturer that is an initial rank in university teaching grades. (Fact Book, 2012). Pakistani women have limited occupational choices due to social and cultural constraints, inherent gender bias, and lack of supportive facilities such as child care, transport, and accommodation at the workplace. Women considered inferior because of predetermined views of employers that women's primary role is housekeeping. (Asian Development Bank, 2000).

Pakistani women are joining higher education institutions for studies and after that for jobs. Although women are part of university academics for long but usually, they are underrepresented in universities. Ghaus (2013) explored that women managers in HE of Pakistan are facing social (familyrelated) and organizational barriers which are more obvious in private sector universities. Older studies of gender inequality in higher education in Pakistan reported that women are facing the issues of sexual harassment (Durrani, 2000).

Mentoring and supportive environments are possible enablers for greater representation of women in higher education (Christiansen \& Slammert 2006). The unwelcoming attitude of higher authorities for women academics is continuously reported in research findings of many studies. Prejudiced practices and micro-politics in the university, undermines the women academics space in decision-making positions (Vinkenburg, Engen, Eagly \& Johannesen-Schmidt, 2011). Women in 
academia have to face structural and socio-cultural barriers as they advance in their careers. (Forster, 2001). Luke (2000) identified that institutional male power and unfair recruitment and selection policies are major barriers in women career growth in academia. Women in academia tend to have higher lecturing and administration workloads as compared to men. But these duties did not get any weightage in the promotion process based on research and publication outputs (Forster, 2001). Morley (2006) stated that the factors that hinder women's career progression in academia included; prejudice about women's intellectual authority, tedious assignments rather than thought-provoking assignments that contribute to their career progress.

\section{Methodology}

The issue being studied in this research was the subjective experience of respondents which they experienced while doing their jobs. Qualitative inductive and interpretive research approach was adopted to seek an in-depth understanding of women academics' professional journey. For data collection, 10 females from two public sector universities of Pakistan were selected purposively; five were associate professor and five were assistant professors. These academics have suspended 10 to 20 years in their profession. They were residing with their spouse and kids and has better socioeconomic status as compared to the other professionals in Pakistan. Although they were performing duties in two public sector universities but they belonged to the different areas of Pakistan, rural and urban some belong to educated families others were not, all disciplines of the university, i.e. social sciences and basic sciences. In this way samples representing female academicians from all over the province of Punjab.

\section{Semi-Structured Interviews}

Face to face semi-structured interviews (Creswell, John, 2010) were conducted for data collection because of the primary consideration that they are well suited for the exploration of the insights and opinions of respondents regarding multifaceted and sometimes sensitive issues (Hutchinson \& Wilson 1992). Informant style of interviewing was adopted which encouraged participants to recall any aspect that is prominent in their memory related to matter of investigation. These surface features are then explored through the process of elaboration based

Table 1. Research participants: Designation and length of experience.

\begin{tabular}{lll}
\hline Pseudonyms & Designation & Experience \\
\hline Zeba & Associate Professor & 20 Years \\
Nadia & Associate Professor & 22 Years \\
Zainab & Associate Professor & 20 Years \\
Amina & Associate Professor & 18 Years \\
Saman & Associate Professor & 15 Years \\
Saima & Assistant Professor & 10 Years \\
Tania & Assistant Professor & 10 Years \\
Fatima & Assistant Professor & 13 Years \\
Rida & Assistant Professor & 10 Years \\
Farah & Assistant Professor & 14 Years \\
\hline
\end{tabular}

On the researcher use of probing (Cooper \& McIntyre, 1996). An interview protocol was developed according to the research question, which was about to explore the journey of career progression of women in academia with particular detail of factors that motivate and discourage them in their career; Discovering the problems, challenges, critical moments discouraging academics? These questions framed the research methodology of the study.

Interviews (conduct, analysis, reporting) were performed by established ethical guidelines in social sciences i.e. acceptance of subjects' right anonymity, confidentiality, and informed consent (Bjarsholm, et al. 2018; Bryman, 2012). The consent of participants was taken by sharing the research questions well before the interview. Anonymity of the interviewee to the information shared is maintained by giving the pseudonym to each participant. Before the start of the interview researcher ensured each interviewee about the anonymity and confidentiality of the given information. This served the purpose of giving them confidence to freely share their views on this particular point that is not only informative, but also explicit. Probing strategy (Hutchinson \& Wilson, 1992) was used by the researcher for the clarification of certain answers. Respondents were asked for exemplification and clarification of certain points and few times, the researcher made probes to keep the interviewee focused on the research question. These explanations enable the researcher to understand points that seemed to oppose what had been said earlier by the respondents. Examples of these types of probing 
questions that the researcher asked to participants were: Could you please share an example of that, any particular reason that you dislike, can you give a more detailed description of what happened? Etc. Each interview was completed in 30 to 40 minutes. To provide valid and reliable data interviews were tape-recorded.

\section{Process of Data Analysis}

Thematic analysis (Guest, MacQueen, 2012) based on the deductive approach was followed for the analysis of interviews. Researchers follow the six-phase guide for conducting thematic analysis provided by Braun \& Clarke (2006). These phases are not necessarily linear, analyst may move forward and back between them. Preliminary data was transcribed. The researcher made the reading and rereading of the story of each woman. Brief notes, comments, and questions arising from reading were marked on transcribed data. Each segment of data that was relevant to or have something interesting about our research questions was coded, an open coding was developed and then codes were modified as the researchers worked through the data. Codes had been organized into themes after repeated readings of transcripts. Coherence, truthfulness, and consistency of themes were considered and comparisons of themes across the interviews were made to determine the similarities and differences of themes and similar themes were merged under one heading e.g. the theme of family support and motivation was merged in one theme and two themes were separated based on differences e.g. respect of teaching profession was divided two different themes prestige of teaching profession in society and likeness for the teaching profession. Institutional politics emerged as a separate theme from the theme of the non-cooperative attitude of senior colleagues. Two categories of main themes were identified and different subthemes were organized under these two main themes i.e. experiences of women about enablers in their career and barriers that female academicians face in their career development. Member checking (respondent validation) (Creswell, 2010) was applied to explore the credibility of results. Member checking was applied to confirm or assess the trustworthiness of qualitative data (Doyle, 2007). Verbatim transcription of five randomly selected respondents were sent back to them to check for correctness and reverberation of their accounts. Respondents were told about member check verification after the interview so, when the transcript return to them, they welcome and willingly verify the data and one participant add some more details in the transcript. The process of verification takes several months because of the busy schedule of participants they could not respond promptly. However, this process of actively involving the contributors in checking and approving the results reduced the potential risk of researcher bias.

\section{Findings and Discussion}

Participants of the study articulated some concerns related to career progression. Academics shared common concerns to some themes, which grouped as subthemes under the main themes of enablers and barriers. Enablers were those influences that smoothed the academic journey women's careers. Barriers are hindrances that academics have faced in their career.
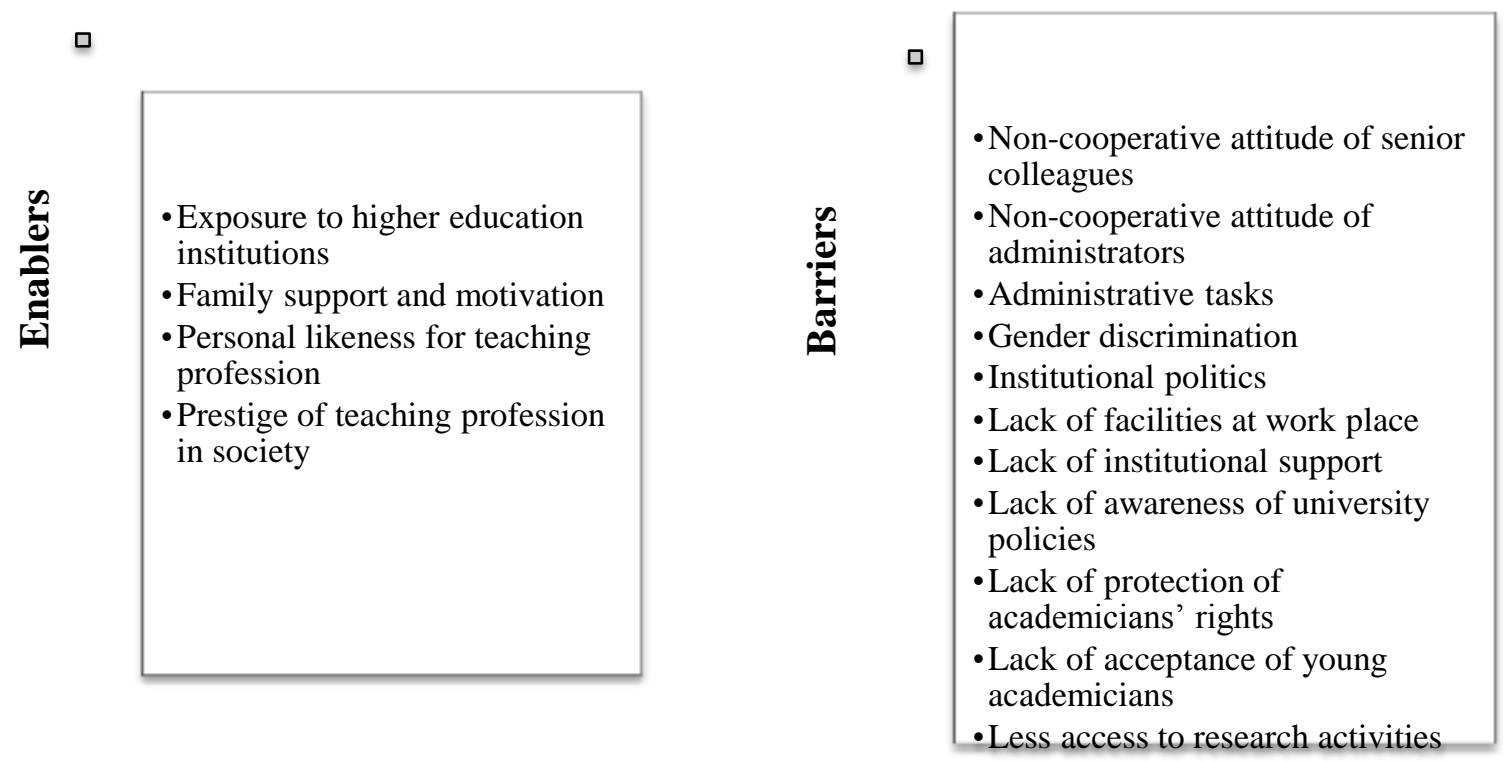

Figure 1. Enablers and Barriers female academics experienced 


\section{Enablers}

Recalling their academic journey, the women academicians acknowledged many factors that contributed positively to their career progression. These factors include: Family support and motivation, exposure to higher education institutions, likeness of academics for the teaching profession, the prestige of the teaching profession in society.

Family support and motivation: Parents were a source of motivation for women academicians. Women in academia are usually inspired by their teachers and parents to select the academic field for job. Zainab added that:

"I am a teacher because my father was a teacher. My father was my teacher as well. I always see the people respecting my father because of his profession. I always like my father contribution to me and my siblings' studies.

Saima said that:

"I joined the teaching profession because my mother was a teacher. I always idealize my mother. If my mother was not in the teaching profession, I might think to join another profession or might be I will not think to be working women."

Sometimes family becomes non-cooperative particularly in-laws. Farah has family-related challenge as she mentions that

"My in-laws dislike my job. The family of in-laws is not cooperative with me. They do not provide support to manage my domestic affairs. I alone manage my domestic responsibilities. This is a great challenge for me sometimes it is hectic to manage."

Morley and Crossouard (2015) also share the expectations of family as a constraint for women who joined academic careers. However, in this study majority of respondents share their experience differently as a family especially parents are a source of motivation and inspiration for women academicians.

Exposure to higher education institutions: University exposure despite hurdles and barrier contribute a lot in the selection of career. All the women have the exposure of high prestige educational institutions although most of interviewee belongs to the remote areas of Pakistan. Some of them got higher degrees from the universities of other developed countries. Fatima added that:

"After joining university, I went abroad to complete my Ph.D. research under the HEC split degree scholarship. Exposure to developed country academic institutes gave me a lot of inspiration to excel in my career. I published my research in journals of international repute."

The researchers conducted in Pakistan showed that women in Pakistan especially in remote areas have less access to the educational institution. Sathar and Haque (2000) have discussed in the findings of their study that less access to schools is a major cause of less enrolment in remote areas of Punjab. It is a general perception that females from rural areas do not get permission due to the narrow-minded attitude of male members of the family. Lack of support of family and fear of female empowerment remained the female away from higher education. The accounts of the interviewees compel us to think against these set notions.

Personal likeness for teaching profession: Female in academia selected the profession because they feel comfortable in this profession as Zeba said that she opted the field of teaching because

"I can express my feelings and knowledge to the students. I feel inner satisfaction when transforms knowledge to students and trained them. I feel that I am contributing positively towards the betterment of an individual.... these feelings give me selfpleasure".

Sharing of feeling is a human instinct. So, it is quite natural if anybody has this type of thinking. Rida asserts that "she enjoyed working with young people (students) and minds." From these comments, it is evident that women academician likes the teaching side mostly.

Prestige of the teaching profession in society: Honor of profession in society served as a motivational factor to join this profession. Women in academia considered that teaching is an honorable profession for women in their society, as Saman responds that "I joined the teaching profession because it is an honor to become a university teacher. Teaching is an 
honorable job for ladies." For academicians, their job is a source of pride, satisfaction, relationships, and strength for them. Tania places her view that:

"To introduce myself as a university teacher is a source of pride for me. People respect the teaching profession. I feel that teaching is considered a respectable profession for women in our male-dominated society. Women feel secure in this profession."

However, one interweaved Rida said that:

"I want to join another field as a profession but my parents force me to join teaching. As teaching is considered a noble profession in society. Although I have adjusted myself in this profession but sometimes, I feel that if my father allows me to join the profession of my own choice it will be enjoyable."

Sometimes women in academia joined the profession for material benefits. For Fatima

"In university teaching salary and other benefits are more than the school and college teaching, handsome salary is one factor that attracts me to join university teaching alongside parents' inspiration. Moreover, teaching at higher education institution

Zeba replied that contribute a lot for my wellbeing"

"I remained active in my life due to my job rather than being at home. My job gives me the confidence to make life decisions. I feel independent to take decisions of my life. I feel that I can't able to do that otherwise".

Females were aware of the effects of their jobs on their wellbeing. Women feel financially strong due to their jobs. They thought that their jobs were helpful to maintain the standards of their lives.

\section{Barriers}

Some barriers highlighted in the articulation of women participants, that they felt jammed the progress of their academic careers. These include; Non-cooperative attitude of senior colleagues, noncooperative attitude of administrators, gender discrimination, institutional politics, lack of facilities at the workplace, lack of institutional support, lack of awareness of university policies, lack of protection of academicians' rights, lack of acceptance of young academicians.

The non-cooperative attitude of senior colleagues: Most of the females have the view that the attitude of senior colleagues was irritating. As, Saima said that

"Leg pulling is a hobby of my senior colleagues. (In response of contextual probing she explained that) they usually complained HOD (head of department) about me for that I have not done. And HOD most of the time trust in their words for me. This situation is annoying for me"

A non-cooperative attitude of administrators: The male administrators are not co-operative with their female subordinates. They have to face the humiliating attitude of male administrative staff. Due to these types of experiences their health suffered. Rida shared her unpleasant experience that:

"In a staff meeting in HOD office, I said that there is load shedding and I don't have fine in my office. It is unbearable to sit on the $2^{\text {nd }}$ floor in the hot summer. HOD just answered that do you sign any agreement with the university that it will provide you such facilities. I am sure he will not answer in such a way if male colleges complain"

Saman said that:

"I could not get permission from HOD for collaborative activities with other universities. He rejected my plan of collaboration just saying that focus on your classes. But when I insist, he further added that it will be difficult for you to manage time for that activity. I realized that HOD is not ready to allow a female. It shows the typical mentality of male members."

Female has to face problems on claim of maternity leave. Tania shares her experience that: "HOD (in response to her maternity leave application) said that you are creating a problem for us by claiming for maternity leave. Maternity leave is my official right. (in response of probing she added) even the Vice chancellor in a faculty meeting said that we avoid hiring young females as they have issues of maternity leave".

It appears from the above comments, that leadership narratives are frequently heard regarding Female subordinates. 
Administrative tasks: The participants have to perform a lot of administrative tasks at the university. Zainab a senior academician shares that:

"During my career, I have performed a lot of administrative tasks at university alongside teaching. I served in charge examination. It is a full-time duty. This administrative task affects my teaching negatively. This extra burden of work affects my health as I feel stress due to this duty."

Most of the respondents are performing different adumbrative tasks e.g. in charge tour committee, timetable management, discipline management, etc.

Gender discrimination: Gender discrimination by male colleagues is a serious problem for female academicians. Women were given a tough time by their male colleagues. Saman shares that "HOD (male) said that how I can give this task to a female teacher as it demands hard work. Male members are preferred for sending on professional trainings."

Institutional politics: Institutional politics is a major challenge for females. Tania shares the example that the

"My male college discourages the students who want to choose me as a research supervisor. Moreover, research projects are only given to the favorite teachers. These opportunities are not shared based on the research interests of teachers."

Some females faced the gender-biased being an only female faculty of their department. Zeba shared that:

"In starting of my career, I was forced to join the group of teachers for departmental politics... when I refuse to go with their side, they use different tactics to tease me i.e. issuance of explanation letters and giving me administrative tasks to increase my workload."

Lack of facilities at campus: One senior academician Zainab share her early career problem that:

"There are no daycare facilities for children at the workplace. Many times, I compelled to think to leave the job as there is no choice to left children during working hours. This problem still exists in most institutions. One colleague recently left the job because no space to left her small baby."

Lack of institutional support: Female professionals were not satisfied with the institutional support provided to them for their career development. Farah mentions that:

"My institution just wants me to teach....... teach all the time nothing else. I usually participate in professional development activities on my expenses. University is not ready to spend on my professional development activities. I want to implement innovations in teaching but due to lake of resources I do not mange."

Lack of awareness of university policies: Academicians have not proper knowledge of the institutional policies. They considered it the negligence of the university, not provides proper information about the policies related to their welfare and progress in university. Sometimes policies are not directly approachable to the teachers. As saman said that:

"I want to take study leave for my Ph.D. studies. But university refuses to give me leave saying that manage your study with teaching. After many years I came to know that study leave was my right and the university can't' refuse to give.

Sometimes lack of awareness about policies is due to the less interest of female teachers as Amina added that "I preferred to be busy in my work rather than being searching for the rights are available or not, are they protected or not."

Lack of protection of academicians' rights: Academicians have the view that the university has given them awareness about their responsibilities very well but not bother about their rights. They feel difficult to defend their rights as Saman added that

"I am not aware of my rights so how can defend. We have to follow our senior's colleges and suppose to do what they are doing. This practice some time hinder our progress in the profession. This sometimes frustrates the teachers."

Saima mentions that "merit policy was not observed in institution most of the time. For the development of a healthy environment in the institution, it should be followed. I think follow the merit is the most important right of academicians." 
Lack of acceptance of young academicians: Female academicians shared their unpleasant experience of the work environment of different nature. Fatima addressed another aspect of being criticized in the work environment. She shared that "being the youngest Ph.D. in my department, my colleagues are not willing to accept me as an assistant professor. They even not give importance to my idea and suggestion."

- Less access to research activities: respondents' continuously mentions that they discourage to avail of research opportunities. Saman a senior academician added that:

"At the start of my career, I am enthusiastic to participate in different research activities. But with time I put aside all of my research ideas because I have a lot of other stuff to do. I rarely manage time for my research related plans. This negligence hinders my career advancement."

\section{Conclusion and Recommendations}

The study deeply explores the experiences of academicians. A glimpse of their professional journey tells us about the enablers and barriers of their career. Findings reveal that females have a very positive attitude towards their profession. They are courageous and hard worker. They have believed that they can cope with all the difficulties of their profession. Nobody mentions that she had to give up their goals at any stage due to hard circumstances. Female academicians have experience of universities in developed countries. Female role models and mentors are mostly their parents they are not idealizing other stars of the field who have a good contribution to their field. That could be the one reason they can't handle the structural barriers and associated difficulties of workplace and competing demands.

In their struggle of profession, they have more barriers as compare to enablers. The frequently described barrier is the biased attitude of male colleagues and administrators. It demonstrates to understand the barriers they confront in their careers and underpins the evolution of a larger cultural change taking place within the university setting. The situation requires changes in the university's strategic plan, with a strong focus on supporting and appointing female at administrative positions. Gender stereotypes are well-documented factors that create resistance to women's influence and authority. Women's contributions are measured against male norms, particularly in research outputs in academia, which creates barriers for those with different styles and career patterns (Obers, 2015). Karen and Pyke (2018) also noted, that all forms of discrimination and bias, including bullying and sexual harassment, is lived experience of all academics. Participants need to develop personal networks or communities, to highlight their diversity and access to information, to emphasize the importance of developing appropriate relational and network support. Senior female academicians can support their young colleagues by giving them advice about handling of these prejudiced attitudes of male colleagues.

Due to work pressure, women have to face work stress that affects their health and performance at the workplace. This negative situation needs the attention of authorities. To address this challenge of workplace administration has to ensure the merit. As there is a criterion for teaching credit hours in every university, the same in the way there should be criteria for the distribution of nonteaching assignments among faculty members. Legislation within the institutions and at the national level should be done to save women against gender bias. Respect of teaching profession in society is an enabler that motivate women academician to join profession. Society has to launch social campaigns for the acceptance of women status outside the home. This study highlights the need for fundamental cultural change in higher education to counter the bias and discrimination by male administrative. Unconscious bias training should be implemented as part of the overall strategy to promote equal opportunity and address the issues of women at all academic levels. There is a need for some type of legislation to avoid gender bias in higher educational institutions. Other critical issues identified were a general lack of understanding and negative perceptions among the female academic is lack of awareness about university policies. Trainings are necessary to give them awareness about institutional policies. Women should provide sufficient opportunities for professional growth. Acceptance of women as an equal and active worker boosts them to give their best in their field. Society can benefit from the true potential of females if they are treated on merit. Universities are the place where highly qualified gentry of state are positioned. If these places fail to give justice to female then the situation remained worse in other fields of work. 


\section{References}

Asian Development Bank (2000). Country Briefing Paper-Women in Pakistan. Bangkok: Asian Development Bank Office of Environment and Social Development

Avin, C., B. Keller, Z. Lotker, C. Mathieu, D. Peleg, \& Y.A. Pignolet. (2015). Homophily and the Glass Ceiling Effect in Social Networks. In Proceedings of Conference on Innovations in Theoretical Computer Science.

Bagilhole, B, \& White, K. (2011). Gender, Power, and Management: A Cross-Cultural Analysis of Higher Education. London: Palgrave Macmillan.

Batool, S. Q., Sajid, M. A. \& Shaheen, I. (2013). Gender and Higher Education in Pakistan. International Journal of Gender and Women's Studies, 1(1), 15-28.

Bjarsholm, D., Gerrevall, P., Linnér, S., Peterson, T., \& Schenker, K. (2018). Ethical considerations in researching sport and social entrepreneurship, European Journal for Sport and Society, 15(3), 216-233, DOI: 10.1080/16138171.2018.1475097

Blackmore, J. \& Sachs, J. (2001). Women leaders in the restructured and internationalized university, in: A Brooks and A McKinnon (Eds) Gender and the Restructured University. Buckingham: Open University Press.

Bombuwela, P.M., \& De Alwis, A.C. (2013). Effects of Glass Ceiling on Women Career Development in Private Sector Organizations Case of Sri Lanka. Journal of Competitiveness, 5, 3-19.

Booysen, L.A.E. \& Nkomo, S.M. (2010). Gender Role Stereotypes and Requisite Management Characteristics: The case of South Africa. Gender in Management: An International Journal, 25, 285-300.

Bryman, A. (2012). Social research methods. Oxford: Oxford University Press.

Calas, M. B., \& Smircich, L. (2009). Feminist perspectives on gender in organizational research: What is and is yet to be. The Sage handbook of organizational research methods, 246-269.

Catalyst (2014). Catalyst Research; Catalyst Historical List of Women CEO's of the Fortune Lists: 1972-2013.http://www.catalyst.org/knowledge/fortune-500-ceopositions-women.

Chanana, K. (2012) Higher education and gender issues in the knowledge economy: who studies what, why, and where? In: D. Neubauer (Ed.) The Emergent Knowledge Society and the Future of Higher Education: Asian Perspectives. Oxford shire, Routledge, 177-193.

Chesterman, C. (2009). Advancing mentoring through a network for women in higher education across continents and contexts. http://www.atn.edu.au/ wexdev/local/docs/advancing mentoring.pdf.

Braun, V., \& Clarke, V. (2006). Using thematic analysis in psychology. Qualitative research in psychology, 3(2), 77-101.

Cook, A. \& Glass, C. (2014). Women and Top Leadership Positions: Towards an Institutional Analysis. Gender, Work and Organization, 21, 91-103.

Cooper, P., McIntyre, D. (1996). Effective Teaching and Learning. Philadelphia: Open University Press.

Creswell, J. W. (2010). Research Design Qualitative and Quantitative Approaches. CA: USA.

Davidson, M. \& Burke, R. (2012) Women in Management Worldwide: Progress and Prospects. An Overview Woman in Management Worldwide, No. 6.

Davis, D. \& Maldonado, C. (2015). Shattering the Glass Ceiling: The Leadership Development of African American Women in Higher Education. Advancing Women in Leadership, 35, 50-66.

Dehaghani, M.V., Cholmaghani, G. \& Goli, M. (2013). Factors Causing the Glass Ceiling in Public Organizations. International Journal of Scientific Research in Knowledge (IJSRK), 1, 106115 .

Doyle, S. (2007). Member checking with older women: A framework for negotiating meaning. Health Care for Women International, 8, 888-908.

Durrani, A. (2000) The Impact of Sexual Harassment on Women Managers in Two of the Higher Educational Institutions in Pakistan. Unpublished M.A. thesis. Institute of Education, University of London.

Fact Book (2012). University of the Punjab. http://pu.edu.pk/document/factbook-latest.pdf

Forster, N. (2001). A case study of women academics' views on equal opportunities, career Prospects and work-family conflicts in a UK university. Career Development International, 6, 28-38. 
Ghaus, B. (2013). Amidst the Barricades: Pakistani Women as Managers in Higher Education. Proceedings of 3rd International Conference on Business Management. Lahore, Pakistan, University of Management and Technology.

Gibson, S. (2006). Mentoring of women faculty: The role of organizational politics and culture. Innovative Higher Education 31: 63-79.

Grove, J. (2013). Prospect of a gladiatorial fight puts women off push for top. Retrieved from: http://www.timeshighereducation.co.uk/news/prospect-ofgladiatorial-fight-puts-women-offpush-for-top/2006612.article.

Guest, G., MacQueen, N., \& Namey, E. (2012). Introduction to thematic analysis. Applied Thematic analysis, 12.

Hannum, K.M., Muhly, S.M., Shockley-Zalabak, P.S. \& White, J.S. (2015). Women Leaders within Higher Education in the United States: Supports, Barriers, and Experiences of Being a Senior Leader. Advancing Women in Leadership, 35, 67-77.

Harris, C. \& Leberman, S. (2011). Leadership Development for Women in New Zealand Universities: Learning from the New Zealand Women in Leadership Program. Advances in Developing Human Resources, 14, 28-44.

Howe-Walsh, Liza, Turnbull, \& Sarah. (2014). Barriers To Women Leaders In Academia: Tales From Science and Technology. Victoria Management School Working Paper:9-11 DOI: 10.1080/03075079.2014.929102

Hutchinson, S., \& Wilson, H. S. (1992). Validity threats in scheduled semi-structured research Interviews. Nursing Research, 41(2), 117-119.

Khan, A.A. (2013).Women, guns, and education. Available online at: http://www.universityworld news.com/article.php?story $=20130717130634784$

Luke, C. (2000). One step up, two down: Women in higher education management in Southeast Asia. In: M. Tight, (Ed.) Academic work and life: What it is to be an academic, and how this is changing. Oxford: Elsevier Science.

Machado-Taylor, M., \& Ozkanli.O. (2013). Gender and Academic Careers in Portuguese and Turkish Higher Education Institutions. Egitim Ve Bilim-Education and Science 38(169): 346-356

Maginn, P. (2010). Breaking through the Glass Ceiling of Local Government? The Gender Profile of Australian Mayors in Metropolitan Australia 1985-2010. FACTBASE Paper No. 11.

Montez, J.M., M. Wolverton, \& W.H. Gmelch. (2003). The Roles and Challenges of Deans. The Review of Higher Education 26(2) 241-266.

Morley, L. \& Crossouard, B. (2015). Women in Higher Education Leadership in South Asia: Rejection, Refusal, Reluctance, Revisioning. University of Sussex; Center for Higher Education \& Equity Research.

Morley, L. (2006). Hidden transcripts: The micro-politics of gender in Commonwealth Universities. Women's Studies International Forum, 29, 543-551.

Murphy, W. \& Kram, K. (2014). Strategic Relationships at Work. New York: McGraw Hill.

Nemoto, K. (2013). When Culture Resists Progress: Masculine Organizational Culture and its Impacts on the Vertical Segregation of Women in Japanese Companies. Work, Employment \& Society, 27, 153-169. http://dx.doi.org/10.1177/0950017012460324

Peterson, H. (2015). Is Managing Academics Women's Work? Exploring the Glass Cliff in Higher Education Management. Educational Management Administration \& Leadership.

Pyke, Karen, D. (2018). Institutional betrayal: Inequity, discrimination, bullying, and retaliation in academia. Sociological Perspectives, 61: 5-13.

Rab, M. (2010). Researching Pakistani Women Academics Life Stories and Feminist Perspectives, paper presented at the 3rd International Conference of Education, Research and Innovation, Madrid, Spain, 15-17 November 2010.

Sathar, Z, \& Haque, M. (2000). Schooling opportunities for girls as a stimulus for fertility changes in rural Pakistan, Policy Research Division Working Paper No. 143 New York: Population Council.

Shah, S. (2001). Tertiary Colleges in Pakistan: Gender and Equality. The School Field, XII (3/4), 4970.

Sharif, M. (2015). Glass Ceiling, the Prime Driver of Women Entrepreneurship in Malaysia: A Phenomenological Study of Women Lawyers. Procedia-Social and Behavioral 
Sciences, 169, 329-336. http://dx.doi.org/10.1016/j.sbspro.2015.01.317

Stanford Report (2014). Women Less Represented in Faculty, Staff Leadership Ranks. http://faculty development.stanford.edu/sites/default/files/urm_report2_exe_sum.pdf

Taylor-Abdulai, Benedicta, Appiah-Kwapong H., Grace L., Sintim-Adasil, S., Emelia, D. \& Akosua. (2014). Socio-Cultural Factors to Breaking Through the Glass Ceiling: A Case Study of University of Ghana, Legon. Social Sciences 3(5): 170-176.

UNESCO Institute of Statistics (2010). Global Education Digest 2010: Comparing Education Statistics Across the World (A Special Focus on Gender). UNESCO, Montreal.

Vinkenburg, C.J., Engen, M.L., Eagly, A.H. \& Johannesen-Schmidt, M.C. (2011) An Exploration of Stereotypical Beliefs about Leadership Styles: Is Transformational Leadership a Route to Women's Promotion? The Leadership Quarterly, 22, 10-21. http://dx.doi.org/10.1016/ j.leaqua.2010.12.003

Wilson, M., Gadbois, S. and Nichol, K. (2008) Is Gender Parity Imminent in the Professoriate? Lessons from One Canadian University. Canadian Journal of Education, 31, 211-228.

Zeng, Z. (2011). The Myth of the Glass Ceiling: Evidence from A Stock-Flow Analysis of Authority Attainment. Social Science Research 40(1): 312-325.

Obers, N. (2015). Influential structures: Understanding the role of the head of department concerning women academics' research careers. Higher Education Research \& Development 34: 122032.

Creswell, J. W. (2010). Mapping the developing landscape of mixed methods research. SAGE handbook of mixed methods in social \& behavioral research, 2, 45-68. 